\title{
An Economic Evaluation of Tofacitinib Treatment in Rheumatoid Arthritis: Modeling the Cost of Treatment Strategies in the United States
}

\author{
Lindsay Claxton, MMath; Michelle Jenks, BA, MSc; Matthew Taylor, MSc; \\ Gene Wallenstein, PhD; Alan M. Mendelsohn, MD; Jeffrey A. Bourret, PharmD; \\ Amitabh Singh, PhD; Dermot Moynagh, MSc; and Robert A. Gerber, PharmD
}

\begin{abstract}
BACKGROUND: Tofacitinib is an oral Janus kinase inhibitor for the treatment of rheumatoid arthritis (RA). Tofacitinib is approved in the United States for use in adults with moderately to severely active RA and an inadequate response or intolerance to methotrexate.

OBJECTIVES: To (a) evaluate, using an economic model, the treatment costs of an RA strategy including tofacitinib, compared with adalimumab, etanercept, certolizumab and tocilizumab biologic RA treatment strategies, which are commonly prescribed in the United States, and (b) assess the economic impact of monotherapy and combination therapy in patients who had an inadequate response to methotrexate therapy (MTX-IR analysis) and to combination therapy in patients who had an inadequate response to a tumor necrosis factor inhibitor (TNF-IR analysis).
\end{abstract}

METHODS: A transparent, Excel-based economic model with a decisiontree approach was developed to evaluate costs over a 1- and 2-year time horizon. The model compared tofacitinib $5 \mathrm{mg}$ twice a day (BID) either as monotherapy or in combination with MTX with similarly labeled biologic therapies. Response to treatment was modeled as American College of Rheumatology (ACR) 20/50/70 response. ACR20 represented clinical response and determined whether patients continued therapy. ACR response rates at 6-month intervals were sourced from prescribing information and safety event rates from a published meta-analysis. Following an adverse event or a lack of response to treatment, it was assumed that $75 \%$ of patients switched to the next line of treatment (first to abatacept and then to rituximab). The perspective was that of a U.S. payer. Costs were reported in 2015 U.S. dollars and included drug wholesale acquisition costs, monitoring, drug administration, and treatment for minor and serious adverse events. The patient population eligible for treatment was based on the total number of members (i.e., RA and non-RA) in a payer organization; members with RA treated with biologic therapies were estimated using epidemiological data. Sensitivity analyses were conducted to explore the impact of varying key parameters, including treatment-switching probability, product rebate, major rates of adverse drug reaction, and ACR20 rates, on the model outcomes.

RESULTS: Tofacitinib combination therapy after MTX failure was associated with the lowest cost per member per month (PMPM) over a 2-year time frame at $\$ 5.53$, compared with $\$ 6.49$ for adalimumab, $\$ 6.43$ for etanercept, $\$ 5.95$ for certolizumab, and $\$ 5.89$ for tocilizumab. Similar savings were observed when all biologics were administered as monotherapy. Tofacitinib combination therapy was also associated with the lower PMPM cost compared with adalimumab combination therapy in the TNF-IR analysis. Tofacitinib was also among the lowest cost per ACR20 responder in each analysis. Sensitivity analyses demonstrated that tofacitinib would potentially be cost saving even in the least optimistic scenarios.

CONCLUSIONS: This analysis suggests that tofacitinib $5 \mathrm{mg}$ BID following MTX failure is a lower cost per patient treatment option when used either as monotherapy or combination therapy, compared with adalimumab, etanercept, certolizumab and tocilizumab biologic regimens. Tofacitinib + MTX in TNF-IR patients was also predicted to be a lower-cost treatment option compared with adalimumab + MTX and was associated with the lowest cost per ACR 20/50/70 responder.

\section{J Manag Care Spec Pharm. 2016;22(9):1088-102}

Copyright $\odot 2016$, Academy of Managed Care Pharmacy. All rights reserved.

\section{What is already known about this subject}

Rheumatoid arthritis (RA) causes a substantial health care and economic burden in direct costs (i.e., medical expenditures) and indirect costs (i.e., lost earnings).

Biologic disease-modifying antirheumatic drugs (DMARDs) have been shown to be cost-effective in modeling analyses.

\section{What this study adds}

Per member per month (PMPM) cost and cost per American College of Rheumatology (ACR) responder economic assessment over $1-2$ years demonstrated that tofacitinib combination therapy after methotrexate (MTX) failure was associated with the lowest cost PMPM over a 2-year time frame, compared with adalimumab, etanercept, certolizumab, and tocilizumab.

Tofacitinib administered as monotherapy after MTX failure was also associated with the lowest cost PMPM over a 2-year time frame, compared with adalimumab strategy, etanercept strategy, certolizumab strategy, and the tocilizumab strategy.

Tofacitinib combination therapy in tumor necrosis factor inhibitor inadequate responder patients was also associated with a lower PMPM cost, compared with adalimumab combination therapy.

$\mathrm{R}$ heumatoid arthritis (RA) is a chronic, systemic autoimmune disease that affects an estimated 1.5 million patients in the United States. ${ }^{1,2}$ It is characterized by inflammation of the synovial membranes, which causes joint swelling, stiffness, and tenderness, and leads to progressive erosion and destruction of cartilage and bone tissue in the affected joints. Wrists, fingers, knees, feet, and ankles are the most commonly affected joints. ${ }^{3,4}$ 
RA causes a substantial health care and economic burden in direct costs (i.e., medical expenditures) and indirect costs (i.e., lost earnings). According to the 2012 Healthcare Cost and Utilization Project (HCUP) Nationwide Inpatient Survey, U.S. patients with RA accounted for $\$ 374$ million in total hospital charges, with a mean charge of $\$ 41,000$ per patient. ${ }^{5}$ The majority of hospital stays were by women and patients aged $\geq 45$ years. ${ }^{5}$ Further, costs attributable to RA are expected to increase because of the aging of the population and increases in obesity and physical inactivity. An analysis of Medical Expenditures Panel Survey (MEPS) data found that in the United States, from 1997 to 2005, total medical care expenditure for adults with arthritis and other rheumatic conditions increased by more than $40 \%$, from $\$ 252$ billion to $\$ 352$ billion. ${ }^{6}$

The goals of treatment are to control disease activity, improve physical functioning and quality of life, and inhibit progression of structural damage throughout the course of the disease. ${ }^{7}$ Treatment of RA is typically initiated with nonsteroidal anti-inflammatory drugs and/or low-dose glucocorticoids, with the introduction of conventional (nonbiologic) diseasemodifying antirheumatic drugs (cDMARDs), typically methotrexate, as quickly as possible after diagnosis.- ${ }^{7-9}$ If methotrexate or other cDMARD treatments do not adequately control disease activity, a biologic agent (bDMARD), usually a tumor necrosis factor (TNF) inhibitor, is typically added to the regimen. If anti-TNF therapy does not elicit an adequate response, it is common to switch the bDMARD either to a bDMARD with a different mechanism of action, or from one TNF inhibitor to another. ${ }^{7,10}$ In the United States, intraclass switching of antiTNF agents is common within clinical practice-over $94 \%$ of rheumatologists (based on 428 completed surveys) reported switching patients from one TNF inhibitor to another because of inadequate response or side effects. ${ }^{11}$

There is a need for new therapeutic options in RA, since not all patients respond to the currently available treatments (primary nonresponders), or they lose response over time (secondary nonresponders). ${ }^{12}$ One such option is tofacitinib, an oral Janus kinase inhibitor for the treatment of RA. It is approved in the United States for use in adults with moderately to severely active RA who also have an inadequate response or intolerance to methotrexate..$^{13}$ Tofacitinib is orally administered and may be prescribed as monotherapy or in combination with methotrexate or other cDMARDs. The recommended dose is $5 \mathrm{mg}$ twice daily. ${ }^{13}$

The efficacy and safety of tofacitinib $5 \mathrm{mg}$ and $10 \mathrm{mg}$ twice daily as monotherapy or in combination with cDMARDs has been demonstrated in phase 2 , phase 3 , and long-term extension studies in patients with moderately to severely active RA. ${ }^{14-18}$ In the 12-month trials, American College of Rheumatology (ACR) response rates in XELJANZ (tofacitinib)-treated patients were consistent at 6 and 12 months.

The purpose of this study was to compare, from a U.S. payer perspective, the treatment costs of an RA strategy that included tofacitinib with biologic RA treatment strategies that included adalimumab, etanercept, certolizumab, and tocilizumab, which are commonly prescribed in the United States. The study also assessed the economic impact of monotherapy and combination therapy in patients who had an inadequate response to methotrexate therapy (MTX-IR analysis) and the economic impact of combination therapy in patients who had an inadequate response to a TNF inhibitor (TNF-IR analysis). This model was developed to establish the clinical and economic value of tofacitinib and the key comparator products to the medical and payer community with an interest in a simple and short-term view of the associated treatment costs of a product.

\section{Methods}

\section{Patients}

Tofacitinib and bDMARDs were evaluated in patients with moderately to severely active RA in 2 patient populations, MTX-IR and TNF-IR patients.

The number of patients eligible for tofacitinib and other treatments was estimated based on the size of the health care organization, the prevalence rate of RA, and the proportion of patients on bDMARDs. For the base case, the organization size was assumed to be constant, at 1 million members, for the course of the model, where the rate of patients leaving the organization and patients joining the organization was assumed to be equal. The Rochester Epidemiology Project provides the most recent evidence on the prevalence rate of RA in the United States, which is estimated at $0.72 \%{ }^{2}$ Myasoedova et al. (2010) carried out a U.S. RA incidence report from Olmsted County, Minnesota. ${ }^{2}$ The study authors applied this rate to the U.S. population more generally; therefore, this rate is likely to be reflective of the wider U.S. population. The proportion of RA diagnosed patients (87\%), DMARD-treated patients (57\%), cDMARD and bDMARD combination treated patients (37\%), and first TNF inhibitor failure rate (40\%) were obtained from IMS LifeLink Health Plan Claims Database, a U.S. health plan insurance claims database containing Medicaid, Medicare, and commercially insured patient data on 64 million unique patients between 2007 and 2011, representing 70\% of the commercially insured population.

\section{Model Structure and Comparators}

An economic model was constructed in Microsoft Excel (Microsoft, Redmond, WA) with the objective of evaluating the costs of treating patients with, and the number of patients responding to, tofacitinib and a number of the most commonly prescribed agents in the United States for RA, including etanercept, adalimumab, certolizumab, and tocilizumab. Selected comparator agents were self-injectable to allow for a more appropriate comparison to tofacitinib. Each comparator included in the model was reflective of the licensed dosage in 


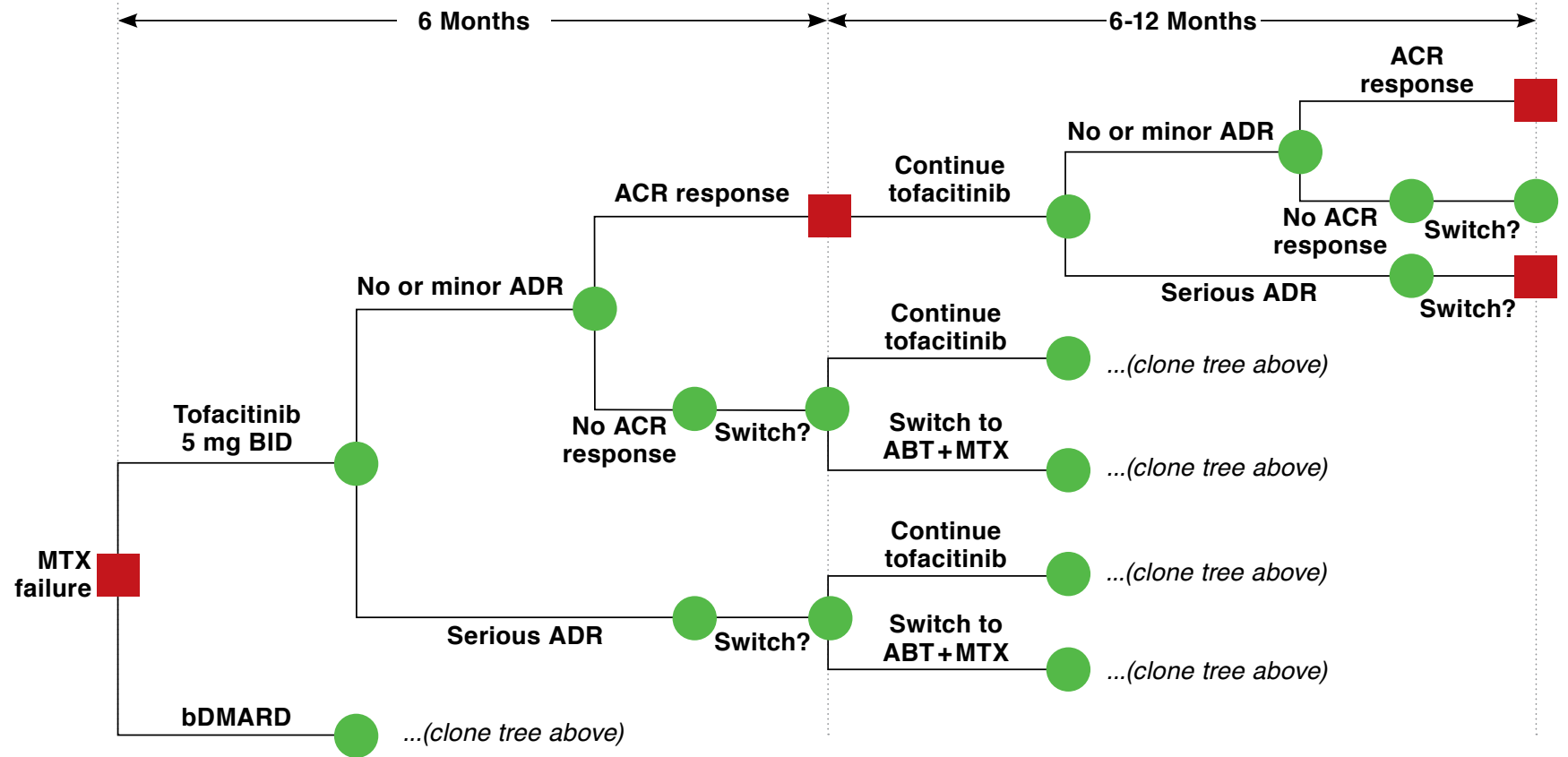

B. TNF-IR Analysis

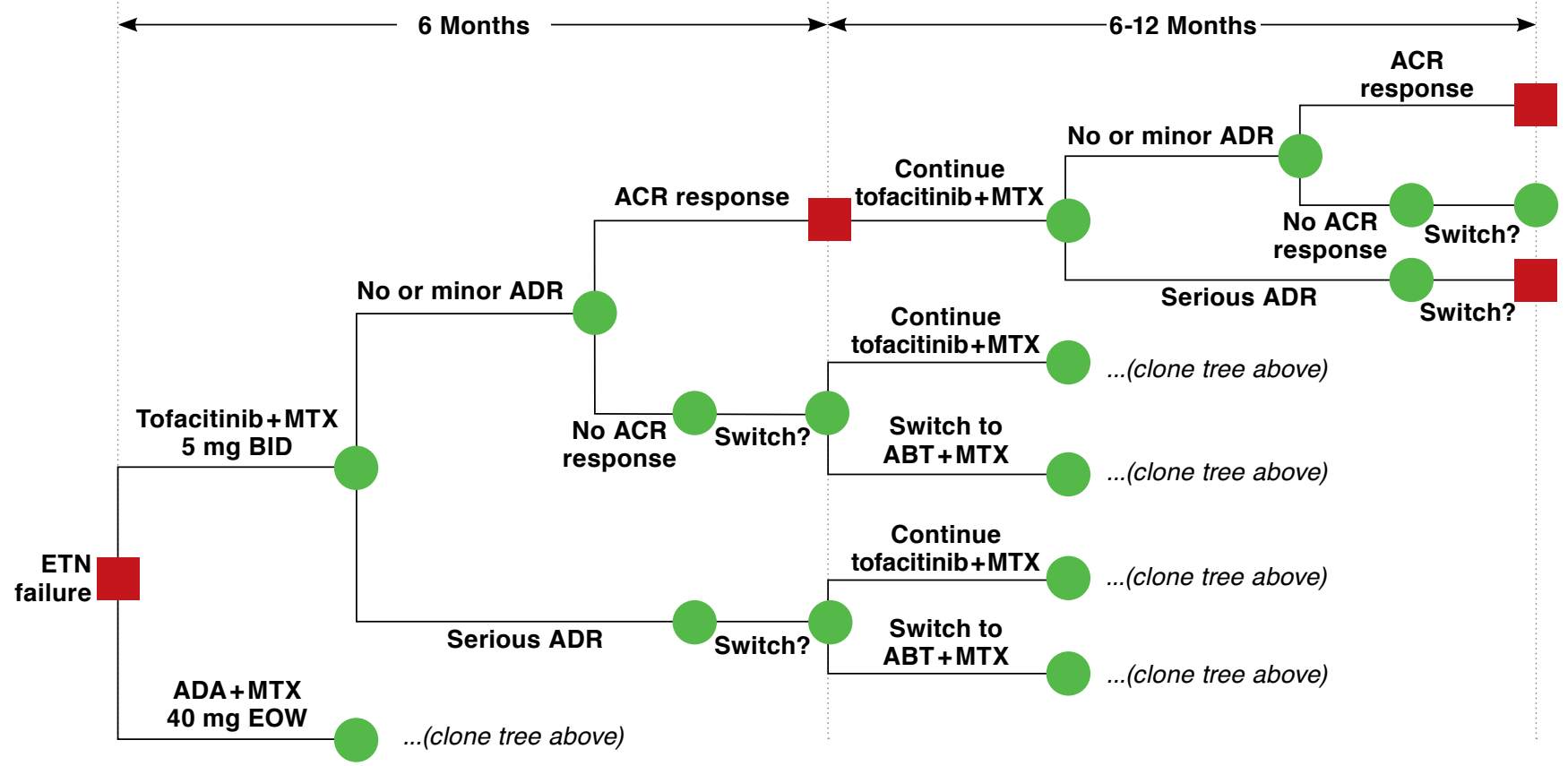

Note: Tofacitinib and biologics in the MTX-IR analysis are modeled either as monotherapy or in combination with MTX.

$A B T=$ abatacept $A C R=$ American College of Rheumatology; $A D A=$ adalimumab; $A D R=$ adverse drug reaction; $b D M A R D=$ biologic disease-modifying antirheumatic drug; $B I D=$ twice per day; EOW: every other week; ETN = etanercept; MTX = methotrexate; MTX-IR=methotrexate inadequate response; TNF-IR=tumor necrosis factor inhibitor inadequate response. 
An Economic Evaluation of Tofacitinib Treatment in Rheumatoid Arthritis: Modeling the Cost of Treatment Strategies in the United States

TABLE 1 Treatment Sequences

\begin{tabular}{|c|c|c|c|c|c|}
\hline & Treatment & Comparator 1 & Comparator 2 & Comparator 3 & Comparator 4 \\
\hline First line & Methotrexate & Methotrexate & Methotrexate & Methotrexate & Methotrexate \\
\hline Second line & Tofacitinib & Adalimumab & Certolizumab & Etanercept & Tocilizumab \\
\hline Third line & Abatacept & Abatacept & Abatacept & Abatacept & Abatacept \\
\hline Fourth line & Rituximab & Rituximab & Rituximab & Rituximab & Rituximab \\
\hline \multicolumn{3}{|c|}{ B. TNF-IR Patients ${ }^{b}$} & & & \\
\hline & Treatment & Comparator & & & \\
\hline First line & Methotrexate & Methotrexate & & & \\
\hline Second line & Etanercept & Etanercept & & & \\
\hline Third line & Tofacitinib & Adalimumab & & & \\
\hline Fourth line & Abatacept & Abatacept & & & \\
\hline Fifth line & Rituximab & Rituximab & & & \\
\hline
\end{tabular}

Note: Sequences are analyses from the point of convergence. In the MTX-IR model, methotrexate is not modeled explicitly; in the TNF-IR model, methotrexate and etanercept are not modeled explicitly.

aTreatments administered either as monotherapy or in combination with methotrexate.

bAll biologic treatments administered in combination with methotrexate.

$M T X-I R=$ methotrexate inadequate responder; TNF-IR=tumor necrosis factor inhibitor inadequate responder.

terms of clinical efficacy, safety, and costs. The model used a decision tree structure, with treatment nodes corresponding to treatment response outcomes for a cohort of patients. Cost and clinical outcomes were evaluated within model cycles of 6 months. These analyses modeled the patient pathway in the short term (over a 1- and 2-year time horizon). The model evaluated a treatment sequence of 3 lines of therapy. In the model, patients switched from one bDMARD to another based on the proportion that achieved an inadequate treatment response or experienced a major adverse drug reaction (ADR). The ACR20 response, a validated primary endpoint in RA clinical trials, was used as a proxy for adequate response to treatment, ${ }^{19}$ which was assessed at 6 months after treatment initiation. The proportion of patients who switch if either of these events occurred was estimated to be $75 \%$, based on an analysis of individual study data identified in a mixed treatment comparison of efficacy, safety and treatment withdrawals in a number of trials for RA. ${ }^{20}$ Figure 1 presents a representation of the model structure.

Table 1 presents the treatment sequences evaluated in the analysis. In the MTX-IR scenarios, all patients entered the model having had an inadequate response to methotrexate. Patients then started treatment on either tofacitinib or a bDMARD, specifically adalimumab, etanercept, certolizumab, or tocilizumab. Treatments were administered either as monotherapy or in combination with methotrexate (combination therapy). Methotrexate as first-line therapy was not modeled explicitly (i.e., patient response, safety, and related costs for this treatment line were not included in the model), since it was common to all treatment arms; instead, the model evaluated the new treatment sequence after MTX-IR (second line in Table 1A, from tofacitinib, adalimumab, certolizumab, etanercept, and tocilizumab).
In the TNF-IR analysis, patients entered the model having had an inadequate response to etanercept. Patients then started treatment on either tofacitinib or adalimumab combination therapy. This sequence was selected because etanercept and adalimumab are among the most commonly prescribed TNF inhibitor agents in the United States. Adalimumab is recommended by the United Kingdom's National Institute for Health and Care Excellence as a treatment option after TNF inhibitor failure. ${ }^{21}$ The TNF-IR analysis did not model methotrexate and etanercept explicitly but evaluated the treatment sequences after TNF-IR (third line in Table 1B, from tofacitinib and adalimumab).

The subsequent sequence of treatment has been assumed to be identical across all treatment sequences. ACR guidelines recommend that if disease activity remains moderate or high despite use of a single TNF inhibitor, a non-TNF bDMARD should be used over another TNF inhibitor. ${ }^{7}$ Patients failing tofacitinib or bDMARD lines of therapy in the model (failing second-line therapy in the MTX-IR analysis or third-line therapy in the TNF-IR analysis) were therefore assumed to switch to abatacept. Following abatacept failure, patients then switched to rituximab combination therapy. Patients on abatacept and rituximab therapy were modeled as being in a TNF-IR population, given that these treatment options followed another bDMARD in the modeled treatment sequences. Rituximab was modeled as combination therapy in all scenarios, in line with the label. ${ }^{22}$

\section{Efficacy and Safety}

The efficacy estimates of treatments were defined based on the ACR20 response rate at 6 months (Table 2). Estimates of the proportion of patients achieving ACR20 response were 


\section{An Economic Evaluation of Tofacitinib Treatment in Rheumatoid Arthritis: Modeling the Cost of Treatment Strategies in the United States}

TABLE 2 ACR Response Rates at 6 Months

\begin{tabular}{|c|c|c|c|c|c|c|c|c|}
\hline \multirow[b]{2}{*}{ Product } & \multicolumn{4}{|c|}{ Monotherapy } & \multicolumn{4}{|c|}{ Combination Therapy } \\
\hline & ACR20 (\%) & ACR50 (\%) & ACR70 (\%) & Source & ACR20 (\%) & ACR50 (\%) & ACR70 (\%) & Source \\
\hline \multicolumn{9}{|c|}{ MTX-IR Patients } \\
\hline Tofacitinib & 69.0 & 42.0 & 22.0 & Fleischmann et al. $2012^{14}$ & 50.0 & 32.0 & 14.0 & Van der Heijde et al. $2013^{18}$ \\
\hline Adalimumab & 46.0 & 22.0 & 12.0 & Van de Putte et al. 200423 & 63.3 & 39.1 & 20.8 & Keystone et al. 200424 \\
\hline Etanercept & 59.0 & 41.0 & 15.0 & Moreland et al. 199925 & 71.0 & 39.0 & 15.0 & Weinblatt et al. 199926 \\
\hline Certolizumab & 46.0 & 23.0 & 6.0 & Fleischmann et al. $2009^{27}$ & 59.0 & 37.0 & 21.0 & Keystone et al. $2008^{28}$ \\
\hline Tocilizumab & 70.0 & 40.0 & 25.0 & Dougados et al. $2013^{29}$ & 51.0 & 25.0 & 11.0 & Kremer et al. $2011^{30}$ \\
\hline Rituximab & N/A & N/A & N/A & N/A & 51.0 & 27.0 & 12.0 & Cohen et al. $2006^{31}$ \\
\hline Abatacept & $50.0^{a}$ & $20.0^{a}$ & $10.0^{\mathrm{a}}$ & Genovese et al. 200532 & 50.0 & 20.0 & 10.0 & Genovese et al. 200532 \\
\hline \multicolumn{9}{|c|}{ TNF-IR Patients } \\
\hline \multicolumn{5}{|l|}{ Tofacitinib } & 51.0 & 37.0 & 16.0 & Burmester et al. $2013^{16}$ \\
\hline \multicolumn{5}{|l|}{ Adalimumab } & 48.2 & 21.2 & 6.8 & $\begin{array}{l}\text { Degraded data from } \\
\text { Keystone et al. } 200424\end{array}$ \\
\hline \multicolumn{5}{|l|}{ Rituximab } & 51.0 & 27.0 & 12.0 & Cohen et al. $2006^{31}$ \\
\hline \multicolumn{5}{|l|}{ Abatacept } & 50.0 & 20.0 & 10.0 & Genovese et al. $2005^{32}$ \\
\hline \multicolumn{9}{|c|}{$\begin{array}{l}\text { Note: Response was dependent on whether the therapy was administered with methotrexate (monotherapy or combination therapy) and whether the therapy was given to } \\
\text { patients who had an inadequate response to methotrexate or to first-line bDMARD. } \\
\text { aThere were no monotherapy data available for abatacept, so it was assumed that the rates were equivalent to that of combination therapy. } \\
\text { ACR=American College of Rheumatology; bDMARD = biologic disease-modifying antirheumatic drug; MTX-IR=methotrexate inadequate responder; N/A=not available; } \\
\text { TNF-IR= tumor necrosis factor inhibitor inadequate responder. }\end{array}$} \\
\hline
\end{tabular}

\section{TABLE 3 Degradation Method to Elicit Adalimumab TNF-IR ACR Response}

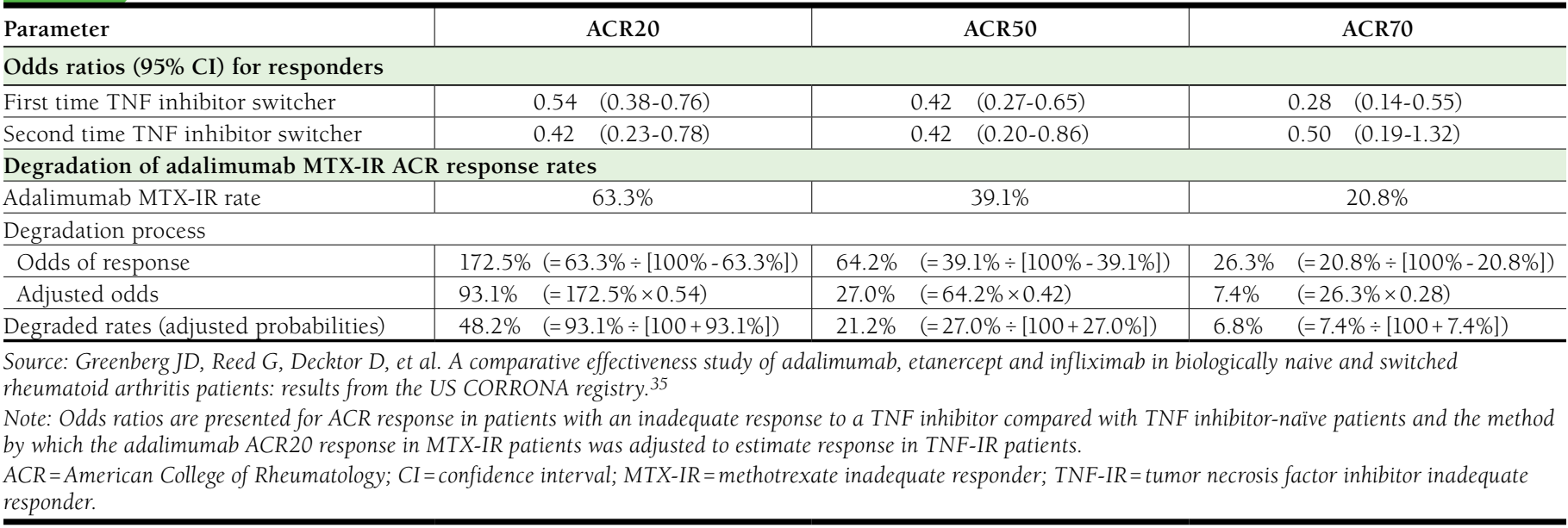

obtained from randomized controlled trial evidence reported in U.S. prescribing information (USPI). ${ }^{14,18,23-32}$ Response to treatment was also dependent on previous cDMARD or bDMARD use, with a lower rate of ACR20 response in patients with a previous inadequate response to a bDMARD, as reflected in appropriate trial data evidence reported in the USPIs. ACR20 response is defined as a $20 \%$ improvement in tender and swollen joint counts from baseline, and a 20\% improvement from baseline in 3 of the 5 remaining ACR-core set measures, which include patient and physician global assessments, patient pain, disability (as measured using the Health Assessment
Questionnaire), and an acute phase reactant (either erythrocyte sedimentation rate or C-reactive protein). ${ }^{33}$ It was assumed that if ACR20 was achieved at 6 months, then it was maintained while the patient continued on the line of therapy. ${ }^{34}$

There were no randomized controlled trials for the efficacy of adalimumab in TNF-IR patients; therefore, TNF-IR responses have been estimated from adalimumab MTX-IR responses. The MTX-IR responses were degraded based on odds ratios estimated by Greenberg et al. (2012) in a study that examined treatment response rate of RA patients in the Corrona US RA registry who were undergoing second-line and third-line 
An Economic Evaluation of Tofacitinib Treatment in Rheumatoid Arthritis: Modeling the Cost of Treatment Strategies in the United States

FIGURE 2 Meta-analysis for Serious ADRs

\begin{tabular}{|c|c|c|c|c|}
\hline Drug & $\begin{array}{c}\text { Trials } \\
(n)\end{array}$ & $\begin{array}{l}\text { Serious Infection Incidence Rate, Patients with } \\
\text { Events per } 100 \text { pt-yrs }(95 \% \mathrm{Cl})^{\mathrm{a}}\end{array}$ & $\begin{array}{l}\text { Patients } \\
\text { (n) }\end{array}$ & $\begin{array}{c}\text { Cumulative } \\
\text { Exposure } \\
\text { (pt-yrs) }\end{array}$ \\
\hline Abatacept & 11 & $\mapsto 0-13.04$ & 5,953 & 6,070 \\
\hline Rituximab & 8 & $\longmapsto \circ-13.72$ & 2,926 & 2,687 \\
\hline Tocilizumab & 13 & $\longmapsto 0 \longrightarrow 5.45$ & 5,547 & 4,522 \\
\hline Infliximab & 11 & $\longmapsto 0 \longrightarrow 6.11$ & 4,592 & 3,555 \\
\hline Etanercept & 17 & $\longmapsto 0 \longrightarrow 4.06$ & 7,141 & 13,037 \\
\hline Certoilzumab pegol & 5 & $\longmapsto-17.59$ & 3,212 & 1,339 \\
\hline Golimumab & 6 & $\longmapsto 0-15.31$ & 2,820 & 1,648 \\
\hline Adalimumab & 18 & $\longmapsto 0$ & 6,570 & 7,095 \\
\hline TNF inhibitor & 57 & •- 4.90 & 26,492 & 29,429 \\
\hline Tofacitinib, Phase 3, $5 \mathrm{mg}$ BID & 6 & $\longmapsto \Delta \smile 3.02$ & 1,587 & 1,464 \\
\hline Tofacitinib, Phase 3, $10 \mathrm{mg}$ BID & 6 & $\longmapsto \Delta \longmapsto 3.00$ & 1,609 & 1,501 \\
\hline Tofacitinib, LTE, 5 mg BID & 1 & $\mapsto \Delta \dashv 2.50$ & 1,452 & 4,005 \\
\hline Tofacitinib, LTE, $10 \mathrm{mg}$ BID & 1 & $\mapsto \triangle \dashv 3.19$ & 3,375 & 5,191 \\
\hline Tofacitinib, Phase 2, Phase 3, LTE (all doses) & 14 & $\mapsto \Delta-12.93$ & 5,671 & 12,664 \\
\hline Adalimumab (tofacitinib, Phase 3, ORAL Standard) & 1 & $\longmapsto 01.68$ & 204 & 179 \\
\hline
\end{tabular}

Source: Strand V, Ahadieh S, French J, et al. Systematic review and meta-analysis of serious infections with tofacitinib and biologic disease-modifying antirheumatic drug treatment in rheumatoid arthritis clinical trials (http://creativecommons.org/licenses/by/4.0/). ${ }^{36}$

aTriangles represent tofacitinib data; circles represent biologic DMARD data.

$A D R=$ adverse drug reaction; $B I D=$ twice a day; $C I=$ confidence interval; $D M A R D=$ disease-modifying antirheumatic drug; LTE=long-term extension; $p t-y r=$ patient-year; TNF= tumor necrosis factor

anti-TNF therapy (patients who had previously failed either 1 or 2 bDMARDs). ${ }^{35}$ The odds of each level of ACR response in first-time switchers to bDMARDs compared with biologically naive patients were estimated. Odds ratios and the calculation steps for estimating the degraded ACR responses for adalimumab are presented in Table 3.

Patients were at risk of an ADR throughout the time horizon of the model. The model considered major and minor ADRs. Major ADR rates were identified in a systematic review and meta-analysis around serious adverse events (including serious infections) associated with treatment with bDMARDs in RA clinical trials (Figure 2) ${ }^{36}$ The study estimated the incidence rate per 100 patient-years for each safety endpoint, which was then converted to a 6-month probability in the model, thus assuming a constant rate of ADR over the modeling time frame.

Minor ADRs included within the analysis were upper respiratory tract infections (URTIs), the most commonly reported adverse event in RA clinical trials. URTI rates were identified from the pooled clinical study results in the USPIs for each comparator and thus are likely to be reflective of MTX-IR and TNF-IR patient populations and treatment strategies (monotherapy and combination therapy). ${ }^{22,37-41}$ In order to take into consideration the variance in minor ADRs in the placebo arms of each of the USPI trials, a naive adjustment was made, whereby the placebo URTI rate from the USPI for each drug was adjusted to reflect the variation in URTI for the placebo arm in each study. All studies were adjusted to reflect the placebo rate from the USPI for tofacitinib, which was equal to 3.3\%.

Rates of serious and minor ADRs were assumed to be the same for combination and monotherapy and in the MTX-IR and TNF-IR patient populations. Major and minor ADR 6-month probabilities are presented in Table 4.

\section{Resource Use and Unit Costs}

Costs included in the model were direct medical costs relevant to a health care payer. Unit costs were taken from national databases and cost sources. ${ }^{5,42,43}$ The resources required to administer treatment, monitor treated patients, and manage ADRs were estimated based on ACR guidelines. ${ }^{44}$ Drug costs, resource use inputs, and unit costs associated with the treatment of major and minor ADRs are shown in Table 5. Costs are denoted in 2015 U.S. dollars.

Drug costs for each comparator over the model time horizon were calculated based on wholesale acquisition cost obtained from RED BOOK Online ${ }^{42}$ and the licensed dosing schedule. ${ }^{22,37-41}$ No product rebates were applied in the base case analysis. The analysis assumed a semiannual wholesale acquisition cost price increase of $6.9 \%$.

The cost of administering treatments intravenously was that of an infusion in an outpatient setting, and the costs were tied 


\section{TABLE 4}

\begin{tabular}{l|c|c|c}
\hline Product & $\begin{array}{c}\text { Major ADR } \\
(\%)\end{array}$ & $\begin{array}{c}\text { Minor ADR } \\
(\%)\end{array}$ & $\begin{array}{c}\text { Placebo-Adjusted } \\
\text { Minor ADR (\%) }\end{array}$ \\
\hline Tofacitinib & 1.50 & 4.50 & 4.50 \\
\hline Adalimumab & 2.49 & 17.00 & 4.32 \\
\hline Etanercept & 2.01 & 13.00 & 4.18 \\
\hline Certolizumab & 3.72 & 6.00 & 9.90 \\
\hline Tocilizumab & 2.69 & 6.00 & 3.30 \\
\hline Rituximab & 1.84 & 2.00 & 3.77 \\
\hline Abatacept & 1.51 & 5.00 & 4.40 \\
\hline
\end{tabular}

Sources: Major ADRs: Strand V, Ahadieh S, French J, et al. Systematic review and meta-analysis of serious infections with tofacitinib and biologic disease-modifying antirheumatic drug treatment in rheumatoid arthritis clinical trials. ${ }^{36}$ Minor ADRs: U.S. prescribing information for each product. 13,22,37-41

${ }^{a}$ Rate of adverse drug events are presented at 6 months for each therapy option. $A D R=$ adverse drug reaction

to the infusion dosing schedule. The cost for subcutaneously administered treatments was that of a single self-injection training session. An initiation visit for the evaluation and management of a new patient and subsequent visits for established patients were incurred for each of the products in the analysis.

Unit costs of monitoring were obtained from the U.S. Medicare fee schedule. ${ }^{43}$ The recommended monitoring resources and visit schedule were based on ACR guidelines, which contain recommendations on treatment for RA based on published clinical evidence and clinical expertise. ${ }^{43}$

The cost associated with a patient experiencing a major ADR was estimated to be $\$ 9,227$, incorporating the cost of treating an episode of pneumonia (the most commonly reported serious infection in RA patients are URTIs) in U.S. hospitals and 2 outpatient visits for follow-up after discharge. The cost of pneumonia was estimated by the Agency for Healthcare Research and Quality and reflects actual expenses incurred by the hospital (e.g., wages, supplies, and utility costs). ${ }^{5}$ Minor ADRs were costed at $\$ 213.52$ and were assumed to be treated with 1 primary care physician visit and a 7-day course of amoxicillin clavulanate, which is a typical assumption for the treatment of URTIs. ${ }^{42,43}$

\section{Model Analysis}

Total costs in the overall eligible population were estimated for each of the treatment sequences. Each sequence is described according to the product that distinguishes it from other sequences (i.e., the arm evaluating the sequence with tofacitinib will be referred to as the tofacitinib arm). The primary outcome of the model was the cost per member (specifically, the member of the organization's plan) per month. The secondary outcomes were the total number of ACR20 responders and the cost per ACR20 response.

A series of sensitivity analyses were conducted to assess the sensitivity of the model to changes in parameter estimates, by observing the impact of changing parameter values on the model results. Parameters considered to be associated with the uncertainty include the treatment switching probability, major ADR probability, ACR20 response rate, and product rebate (up to $20 \%$ ). Threshold analysis was also conducted for each of these parameters. A 2-way sensitivity analysis included simultaneously varying the rebate level and ACR response rate. Costs reported were those accrued over 2 years.

\section{Results}

The base case analyses evaluated the treatment costs of tofacitinib in patients with moderately to severely active RA compared with different bDMARDs licensed for use in the U.S. market. In the MTX-IR analysis, these comparators included adalimumab, etanercept, certolizumab, and tocilizumab. In the TNF-IR analysis, tofacitinib was compared with adalimumab. Clinical and cost outcomes were assessed at 1 and 2 years.

Using an organization size of 1 million patients, combined with epidemiological data, resulted in an estimated 7,200 patients with RA in the population, of which 6,264 were estimated to have received a diagnosis. Of those diagnosed patients, it was estimated that there were 1,321 RA patients on bDMARDs in the MTX-IR population and 528 RA patients on bDMARDs in the TNF-IR population.

Similar conclusions were observed in the MTX-IR and the TNF-IR analysis. In both patient populations, tofacitinib was associated with the lowest total costs; per member per month (PMPM) cost; and cost per ACR20, ACR50, and ACR70 responders compared with each bDMARD comparator over 1 and 2 years. The cost savings arise mainly because of lower drug and administration costs and ADR treatment costs (because of lower serious ADR rates for tofacitinib compared with adalimumab).

\section{MTX-IR Analysis}

Results for the MTX-IR analyses are presented in Table 6. The cost breakdown is presented in Figure 3A-B. For monotherapy treatment options, the cost PMPM for tofacitinib was $\$ 5.36$, compared with $\$ 6.33$ for adalimumab, $\$ 6.30$ for etanercept, $\$ 5.88$ for certolizumab, and $\$ 5.79$ for tocilizumab. For combination therapy treatment options, the cost PMPM for tofacitinib monotherapy was $\$ 5.53$, compared with $\$ 6.49$ for adalimumab, $\$ 6.43$ for etanercept, $\$ 5.95$ for certolizumab, and $\$ 5.89$ for tocilizumab.

\section{TNF-IR Analysis}

Table 7 reports the outcomes for the TNF-IR subpopulation. The cost breakdown is presented in Figure 3C. At 2 years, tofacitinib combination therapy was associated with a cost PMPM of $\$ 2.21$ and a cost per ACR20 responder of $\$ 132,500$, compared with a cost PMPM of $\$ 2.57$ and a cost per ACR20 responder of $\$ 157,273$ for adalimumab. 


\section{An Economic Evaluation of Tofacitinib Treatment in Rheumatoid Arthritis: Modeling the Cost of Treatment Strategies in the United States}

\section{TABLE 5 Unit Costs and Resource Use}

\begin{tabular}{|c|c|c|c|}
\hline$\underline{\text { Product }}$ & Unit Cost & Frequency and Administration Mode & Source \\
\hline Lipid panel & $\$ 97.00$ & $\begin{array}{l}\text { Includes: cholesterol, serum, total lipo- } \\
\text { protein, direct measurement, high-density } \\
\text { cholesterol, and triglycerides } \\
\text { Administered } 4-8 \text { weeks following } \\
\text { initiation of tofacitinib therapy }\end{array}$ & $\begin{array}{l}\text { Physician's Fee and Coding Guide } \\
\text { (HCPCS code 80061) }\end{array}$ \\
\hline Atorvastatin & $\$ 0.73$ (daily drug cost) & $\begin{array}{l}\text { Used while on tofacitinib } \\
20 \mathrm{mg} \text { daily } \\
\text { Orally administered }\end{array}$ & RED BOOK Online ${ }^{42}$ \\
\hline Tuberculin or Mantoux test & $\$ 30.50$ & $\begin{array}{l}\text { Skin test: tuberculosis, intradermal } \\
\text { Administered annually for all biologics }\end{array}$ & $\begin{array}{l}\text { Physician's Fee and Coding Guide } \\
\text { (HCPCS code 86580) }\end{array}$ \\
\hline Chest x-ray & $\begin{array}{l}\$ 109.00 \text { (mid-point of cost range } \\
\$ 97-\$ 121)\end{array}$ & Applied annually for all biologics & $\begin{array}{l}\text { Physician's Fee and Coding Guide } \\
\text { (HCPCS code } 71010)^{43}\end{array}$ \\
\hline $\begin{array}{l}\text { Evaluation and management } \\
\text { visit for } x \text {-ray }\end{array}$ & $\begin{array}{l}\$ 53.00 \text { (mid-point of cost range } \\
\$ 45-\$ 61)\end{array}$ & Annually for all biologics & $\begin{array}{l}\text { Physician's Fee and Coding Guide } \\
\text { (HCPCS code 99211) } 43\end{array}$ \\
\hline CBC with differential & $\$ 43.00$ & $\begin{array}{l}\text { Blood count: complete (CBC), automated } \\
\text { (Hgb, Hct, RBC, WBC, and platelet } \\
\text { count). } \\
\text { Administered before initiation for all } \\
\text { biologics per ACR guidelines }\end{array}$ & $\begin{array}{l}\text { Physician's Fee and Coding Guide } \\
\text { (HCPCS code 85027) }\end{array}$ \\
\hline Hepatic panel test & $\$ 61.00$ & $\begin{array}{l}\text { Includes: albumin, bilirubin, phosphatase, } \\
\text { alkaline protein, total transferase, alanine } \\
\text { aminotransferase, aspartate aminotransferase } \\
\text { Administered on initiation for biologics, } \\
\text { per ACR guidelines } \\
\text { Five in the first } 6 \text { months and } 2 \text { in next } \\
6 \text { months for methotrexate }\end{array}$ & $\begin{array}{l}\text { Physician's Fee and Coding Guide } \\
\text { (HCPCS code 80076) }\end{array}$ \\
\hline Treatment of pneumonia & $\$ 8,853$ & Treatment for serious ADR & HCUPnet $2012^{5}$ \\
\hline Outpatient follow-up visit & $\begin{array}{l}\$ 187.00 \text { (mid-point of cost range } \\
\$ 159-\$ 215)\end{array}$ & $\begin{array}{l}\text { Costs for } 2 \text { visits were applied } \\
\text { Treatment for ADR } \\
\end{array}$ & $\begin{array}{l}\text { Physician's Fee and Coding Guide } \\
\text { (HCPCS code 99214) }\end{array}$ \\
\hline Amoxicillin clavulanate & $\begin{array}{l}\$ 2.36 \text { (daily cost) } \\
\text { (based on } \$ 23.60 \text { for } 20 \text { tablets) }\end{array}$ & $\begin{array}{l}\text { 7-day course; } 875 \mathrm{mg} \text { tablet every } \\
12 \text { hours } \\
\text { Treatment for minor ADR } \\
\text { Orally administered } \\
\end{array}$ & RED BOOK Online $e^{42}$ \\
\hline $\begin{array}{l}\text { Primary care physician } \\
\text { visit }\end{array}$ & $\begin{array}{l}\$ 197.00 \text { (mid-point of cost range } \\
\$ 168-\$ 226)\end{array}$ & \begin{tabular}{|l|} 
I visit \\
Treatment for minor ADR \\
\end{tabular} & $\begin{array}{l}\text { Physician's Fee and Coding Guide } \\
\text { (HCPCS code 99203) }{ }^{43}\end{array}$ \\
\hline Initiation visit & $\begin{array}{l}\$ 197.00 \text { (mid-point of cost range } \\
\$ 168-\$ 226 \text { ) }\end{array}$ & At initiation of each biologic therapy & $\begin{array}{l}\text { Physician's Fee and Coding Guide } \\
\text { (HCPCS code 99203) } 43\end{array}$ \\
\hline Subsequent visit & $\begin{array}{l}\$ 123.50 \text { (mid-point of cost range } \\
\$ 105-\$ 142 \text { ) }\end{array}$ & Visit every 3 months & $\begin{array}{l}\text { Physician's Fee and Coding Guide } \\
\text { (HCPCS code 99213) }{ }^{43}\end{array}$ \\
\hline Training & $\begin{array}{l}\$ 95.00 \text { (mid-point of cost range } \\
\$ 81-\$ 109)\end{array}$ & $\begin{array}{l}\text { At initiation of biologic therapies admin- } \\
\text { istered as self-injection (etanercept, } \\
\text { adalimumab, tocilizumab, certolizumab, } \\
\text { and abatacept) }\end{array}$ & $\begin{array}{l}\text { Physician's Fee and Coding Guide } \\
\text { (HCPCS code 99201) } 43\end{array}$ \\
\hline Infusion & $\begin{array}{l}\$ 504.50 \text { (cost per hour) } \\
\text { (mid-point of cost range } \$ 429-\$ 580 \text { ) }\end{array}$ & $\begin{array}{l}\text { Tocilizumab: infusion over } 1 \text { hour } \\
\text { Rituximab: infusion over } 3 \text { hours } \\
\text { Abatacept: infusion over } 1 \text { hour } \\
\text { See dosing schedule for applicable } \\
\text { biologics }\end{array}$ & $\begin{array}{l}\text { Physician's Fee and Coding Guide } \\
\text { (HCPCS code 96413) }\end{array}$ \\
\hline Abatacept injection & $\$ 864.08$ (125 mg/mL syringe) & $\begin{array}{l}\text { Injection once weekly } \\
\text { Self-administered subcutaneous injection }\end{array}$ & RED BOOK Online $e^{42}$ \\
\hline Abatacept vial & $\$ 849.44$ (250 mg vial) & $\begin{array}{l}\text { Loading dose of } 3 \text { vials at initiation } \\
\text { Administered by intravenous infusion }\end{array}$ & RED BOOK Online $e^{42}$ \\
\hline Adalimumab & $\begin{array}{l}\$ 1,898.55(40 \mathrm{mg} / 0.8 \mathrm{~mL} \text { pen } \\
\text { injector kit) }\end{array}$ & $\begin{array}{l}40 \text { mg every other week } \\
\text { Self-administered subcutaneous injection }\end{array}$ & RED BOOK Online $e^{42}$ \\
\hline
\end{tabular}




\section{An Economic Evaluation of Tofacitinib Treatment in Rheumatoid Arthritis: Modeling the Cost of Treatment Strategies in the United States}

\begin{tabular}{|c|c|c|c|}
\hline Certolizumab & $\begin{array}{l}\$ 3,344.59(400 \mathrm{mg} / 2 \mathrm{~mL} \\
\text { syringe kit) }\end{array}$ & $\begin{array}{l}200 \text { mg every } 4 \text { weeks } \\
\text { Self-administered subcutaneous injection }\end{array}$ & RED BOOK Online $e^{42}$ \\
\hline Etanercept & $\$ 932.16$ (50 mg/mL syringe) & $\begin{array}{l}50 \mathrm{mg} \text { once weekly } \\
\text { Self-administered subcutaneous injection }\end{array}$ & RED BOOK Online $e^{42}$ \\
\hline Rituximab & $\$ 774.07(10 \mathrm{mg} / \mathrm{mL}$ vial $)$ & $\begin{array}{l}\text { One infusion of } 1 \mathrm{gm} \text {, followed by a } \\
\text { second infusion of } 1 \text { gm after } 2 \text { weeks. } \\
\text { Course is repeated every } 6 \text { months. } \\
\text { Administered by intravenous infusion }\end{array}$ & RED BOOK Online $e^{42}$ \\
\hline Tocilizumab & $\$ 819.48(80 \mathrm{mg} / \mathrm{mL}$ vial $)$ & $\begin{array}{l}\text { One infusion of a } 400 \mathrm{~mL} \text { vial, followed } \\
\text { by a subcutaneous injection every week } \\
\text { Intravenous infusion and self-administered } \\
\text { subcutaneous injection }\end{array}$ & RED BOOK Online $e^{42}$ \\
\hline Tofacitinib & $\$ 52.82$ (cost per $5 \mathrm{mg}$ tablet) & $\begin{array}{l}5 \mathrm{mg} \text { twice a day } \\
\text { Orally administered }\end{array}$ & RED BOOK Online $e^{42}$ \\
\hline
\end{tabular}

$A C R=$ American College of Rheumatology; $A D R=$ adverse drug reaction; $C B C=$ complete blood count; HCPCS = Healthcare Common Procedure Coding System; $H c t=$ hematocrit; $\mathrm{Hg} b=$ hemoglobin; $\mathrm{RBC}=$ red blood cell count; $\mathrm{WBC}=$ white blood cell count

\section{TABLE 6 Results of MTX-IR Monotherapy and Combination Therapy}

\begin{tabular}{|c|c|c|c|c|c|}
\hline & Tofacitinib & Adalimumab & Etanercept & Certolizumab & Tocilizumab \\
\hline \multicolumn{6}{|l|}{ MTX-IR Monotherapy } \\
\hline \multicolumn{6}{|l|}{1 year } \\
\hline Total cost & $\$ 60,607,294$ & $\$ 74,368,973$ & $\$ 73,169,567$ & $\$ 67,909,788$ & $\$ 66,396,638$ \\
\hline Cost PMPM & $\$ 5.05$ & $\$ 6.20$ & $\$ 6.10$ & $\$ 5.66$ & $\$ 5.53$ \\
\hline ACR20 responders & 1,055 & 864 & 971 & 855 & 1,059 \\
\hline Cost per ACR20 responder & $\$ 57,424$ & $\$ 86,096$ & $\$ 75,335$ & $\$ 79,418$ & $\$ 62,690$ \\
\hline \multicolumn{6}{|l|}{2 years } \\
\hline Total cost & $\$ 128,596,040$ & $\$ 151,904,799$ & $\$ 151,268,017$ & $\$ 141,096,133$ & $\$ 139,014,925$ \\
\hline Cost PMPM & $\$ 5.36$ & $\$ 6.33$ & $\$ 6.30$ & $\$ 5.88$ & $\$ 5.79$ \\
\hline ACR20 responders & 1,115 & 967 & 1,050 & 960 & 1,118 \\
\hline Cost per ACR20 responder & $\$ 115,286$ & $\$ 157,072$ & $\$ 144,025$ & $\$ 146,919$ & $\$ 124,309$ \\
\hline \multicolumn{6}{|l|}{ MTX-IR Combination Therapy } \\
\hline \multicolumn{6}{|l|}{1 year } \\
\hline Total cost & $\$ 63,127,535$ & $\$ 75,726,239$ & $\$ 74,467,450$ & $\$ 68,860,603$ & $\$ 68,503,703$ \\
\hline Cost PMPM & $\$ 5.26$ & $\$ 6.31$ & $\$ 6.21$ & $\$ 5.74$ & $\$ 5.71$ \\
\hline ACR20 responders & 900 & 1,004 & 1,069 & 961 & 903 \\
\hline Cost per ACR20 responder & $\$ 70,123$ & $\$ 75,448$ & $\$ 69,676$ & $\$ 71,635$ & $\$ 75,830$ \\
\hline \multicolumn{6}{|l|}{2 years } \\
\hline Total cost & $\$ 132,687,087$ & $\$ 155,709,298$ & $\$ 154,258,796$ & $\$ 142,891,347$ & $\$ 141,432,866$ \\
\hline Cost PMPM & $\$ 5.53$ & $\$ 6.49$ & $\$ 6.43$ & $\$ 5.95$ & $\$ 5.89$ \\
\hline ACR20 responders & 995 & 1,075 & 1,126 & 1,043 & 998 \\
\hline Cost per ACR20 responder & $\$ 133,311$ & $\$ 119,388$ & $\$ 114,748$ & $\$ 123,492$ & $\$ 132,923$ \\
\hline
\end{tabular}

Note: The analysis for this table is based on 1,321 treated patients. The cost PMPM is based on the total number of 1 million organization (plan) members. $A C R=$ American College of Rheumatology; MTX-IR= methotrexate inadequate responder; $P M P M=$ per member per month.

\section{Sensitivity Analysis}

Tofacitinib was estimated to be cost saving compared with the other comparators over a wide range of ACR20 rates (Figure 4). Cost PMPM for tofacitinib compared with the bDMARDs does not overlap even when the ACR20 rate is simultaneously improved by $75 \%$ for comparators and decreased by $75 \%$ for tofacitinib. As such, there is no threshold value for ACR20 for which tofacitinib is no longer a cost-saving option.
Figure 5 presents the impact of different levels of drug rebates applied to each comparator in each of the analyses. The cost PMPM for tofacitinib when no rebate is applied remains lower than that for adalimumab and etanercept bDMARDs when a 20\% rebate is applied. A large rebate for the other comparators was required for tofacitinib to no longer be cost saving. In the MTX-IR combination therapy analysis, the required rebates are approximately 23\% for adalimumab, $21 \%$ for 
An Economic Evaluation of Tofacitinib Treatment in Rheumatoid Arthritis:

Modeling the Cost of Treatment Strategies in the United States

\section{FIGURE 4 Sensitivity Analyses: Varying} ACR Response Rates

\section{A.MTX-IR Monotherapy}

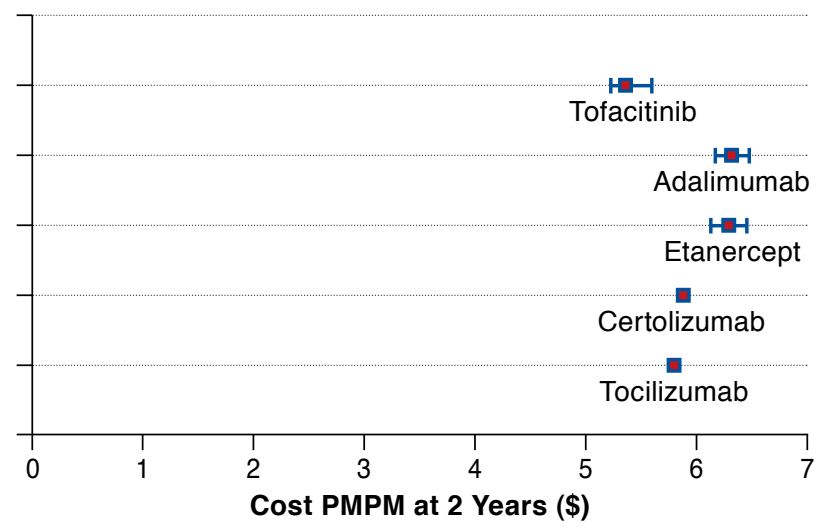

\section{B. MTX-IR Combination Therapy}

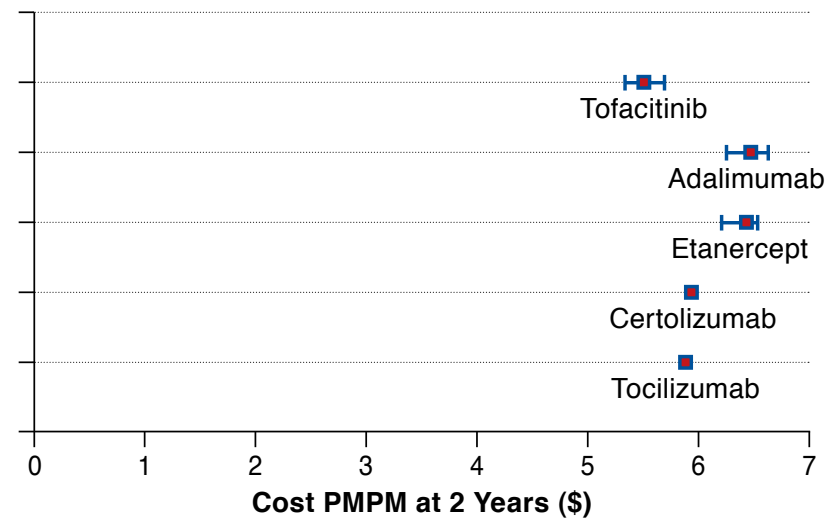

\section{C.TNF-IR Combination Therapy}

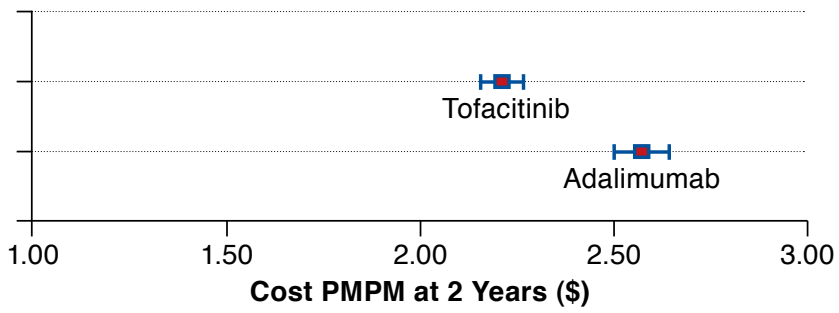

Note: Impact on model outcomes are shown when varying the ACR20 response rates for tofacitinib and adalimumab. Base case results (the cost PMPM for tofacitinib, adalimumab, and etanercept, respectively) represented by the red squares, with values corresponding to increased ACR 20 rates by $\pm 75 \%$ represented by the horizontal bars.

$A C R=$ American College of Rheumatology; MTX-IR = methotrexate inadequate responder; $P M P M=$ per member per month; TNF-IR= tumor necrosis factor inhibitor inadequate responder.

\section{FIGURE 5 Sensitivity Analyses: Level of Rebate}

\section{A. MTX-IR Monotherapy}

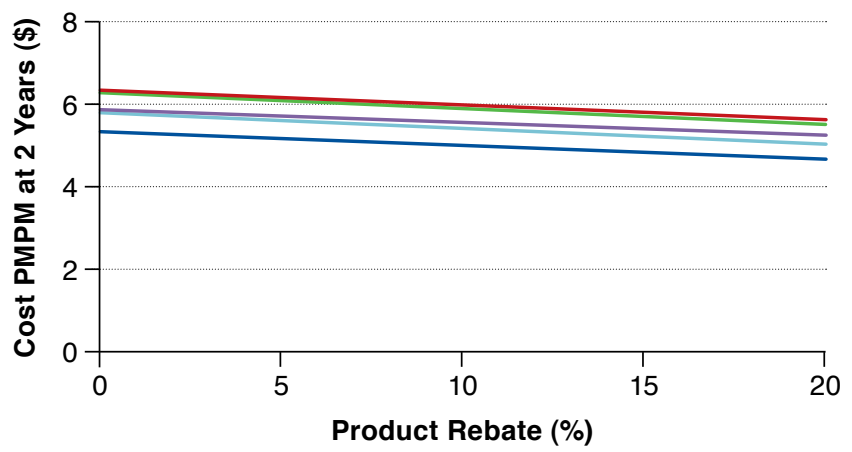

B. MTX-IR Combination Therapy

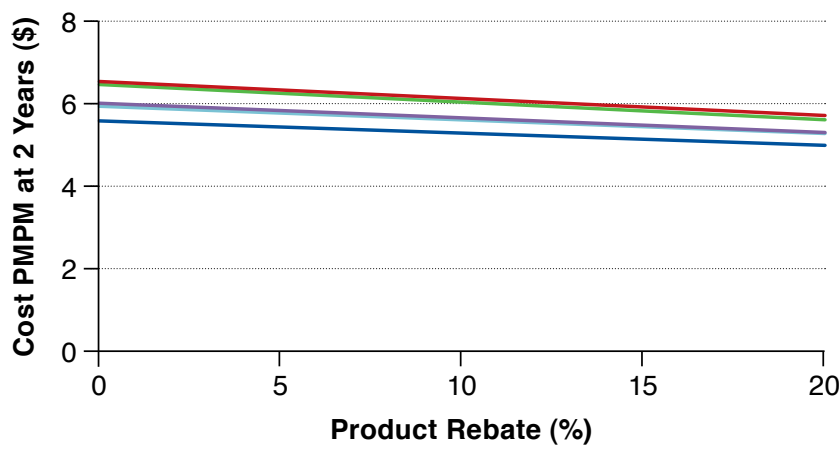

\section{TNF-IR Combination Therapy}

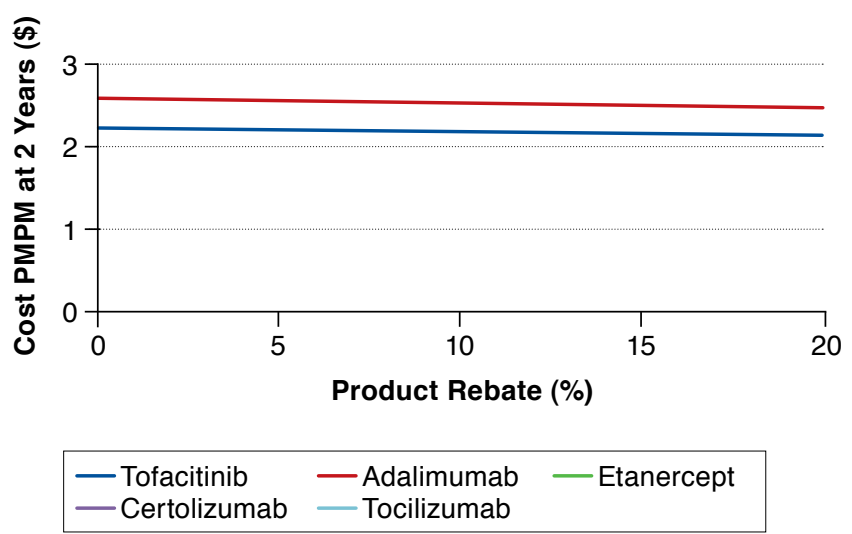

Note: The impact of applying varying levels of product rebate on the model results is shown here. The colored lines represent the cost PMPM for each therapy, with different levels of rebate applied.

$M T X-I R=$ methotrexate inadequate responder; $P M P M=$ per member per month; $T N F-I R=$ tumor necrosis factor inhibitor inadequate responder. 


\section{FIGURE 6 Sensitivity Analyses: Treatment Switching}

\section{A. MTX-IR Monotherapy}

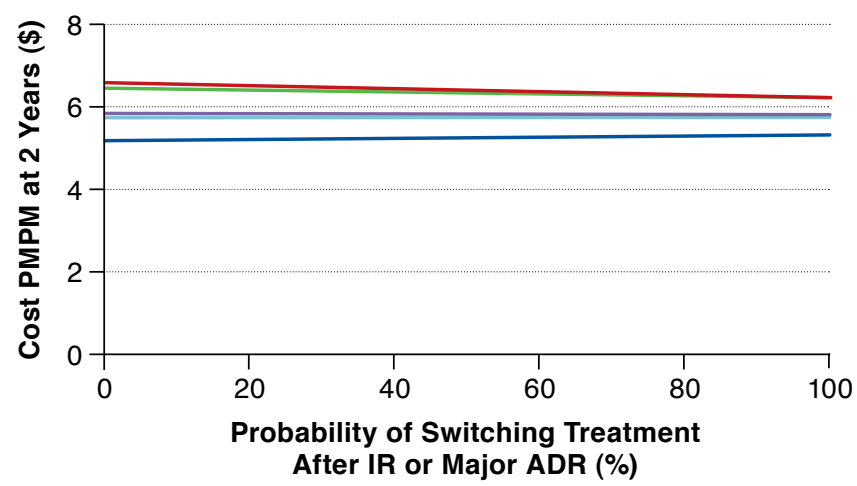

\section{B. MTX-IR Combination Therapy}

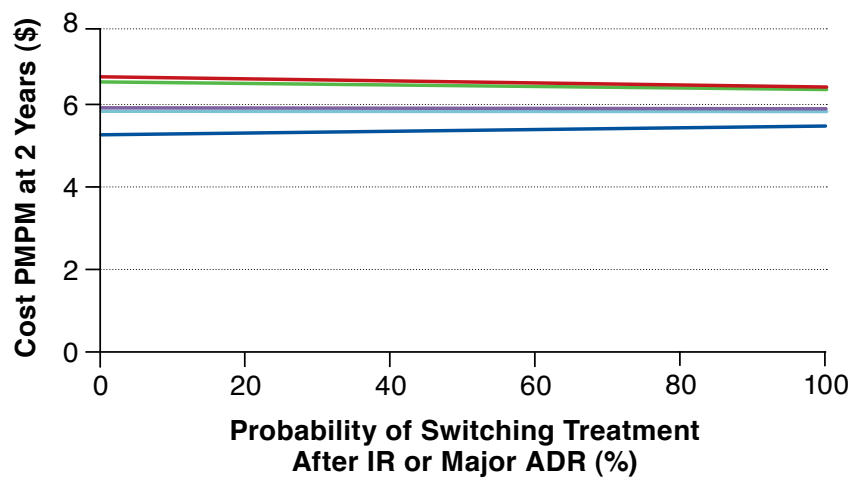

\section{TNF-IR Combination Therapy}

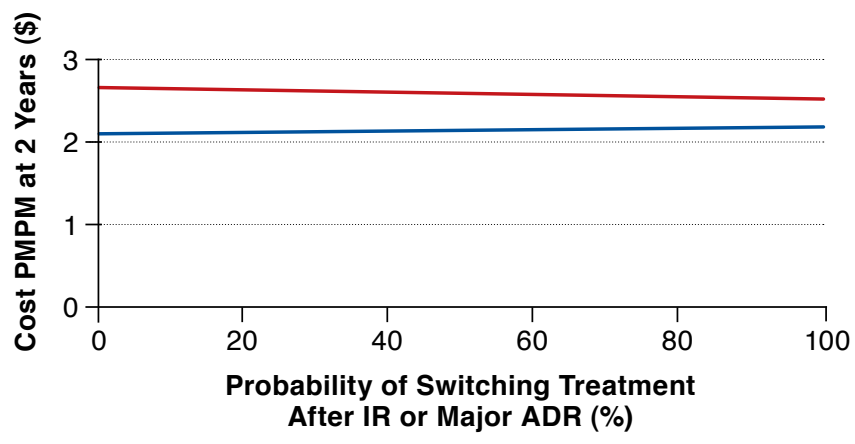

$\begin{array}{|ll|}\text { - Tofacitinib } & \text { - Adalimumab } \\ \text { Certolzumab } & \text { Tocilizumab }\end{array}$

Note: The impact of varying the treatment switching probability on the model result is shown here.

$A D R=$ adverse drug reaction; $I R=$ inadequate response; $M T X-I R=$ methotrexate inadequate responder; PMPM = per member per month; TNF-IR=tumor necrosis factor inhibitor inadequate responder.

\section{Limitations}

The present study demonstrates that tofacitinib may be a cost-saving treatment strategy compared with other strategies. These findings could have implications for managed care organizations as they evaluate benefit design and treatments for RA. However, this model has some limitations to consider. First, this model included a cross-trial efficacy and safety comparison of trials that were not performed contemporaneously. It is possible that the patient populations are not comparable (e.g., different disease severity and disease duration at baseline), although this is unlikely given the similar labels for each product. Rates of treatment response and adverse events may have been influenced by these factors. Rates estimated in a mixed treatment comparison have been published in a conference abstract and were demonstrated to be similar to those in each individual USPI20; however, given the lack of detail on methodology in the abstract, it was felt preferable to use data from the USPIs.

Second, there were no available data to represent response to adalimumab robustly in a TNF-IR population. By using the degradation method to adjust the MTX-IR ACR response rates for this comparator, the estimated response rates were more likely to better reflect patients who have switched from another bDMARD, since those who switch are less likely to respond to further lines of treatment. ${ }^{35}$ The alternative assumption that response rates are equal for TNF-IR and MTX-IR patients would have likely overestimated the response rate for the TNF-IR patient population, so it was not included in the analysis. Sensitivity analysis around ACR20 rates demonstrated that the model results were robust to this parameter.

Third, the treatment sequence was fixed in a linear method; that is, after either tofacitinib or the bDMARD comparator, patients always moved to abatacept and then to rituximab. However, it is often the case that the reason for failure (e.g., adverse events or loss of effectiveness) may affect the choice of the next therapy. This may also have an effect on the effectiveness of the subsequent treatment. This is the case with patients treated with an initial TNF inibitor who demonstrated no evidence of efficacy after 6 months (primary nonresponders), who stepped through to a second TNF inhibitor. At present, there is little evidence on this issue to be able to consider this effect in the model because RA disease activity is not routinely measured or captured and, as such, was not included in the analysis. It is also difficult to predict the direction of the bias in the results, but it may be that patients would go to the line of therapy deemed to be the most appropriate given their medical histories, and as such, the current estimate of effectiveness in subsequent lines of treatment may underestimate the true impact. 


\section{FIGURE 7 Sensitivity Analyses: Major ADR Probability}

\section{A. MTX-IR Monotherapy}

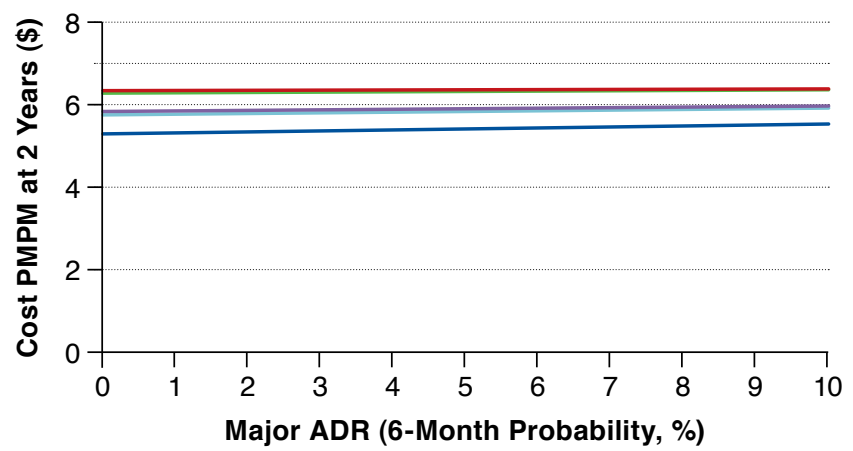

\section{B. MTX-IR Combination Therapy}

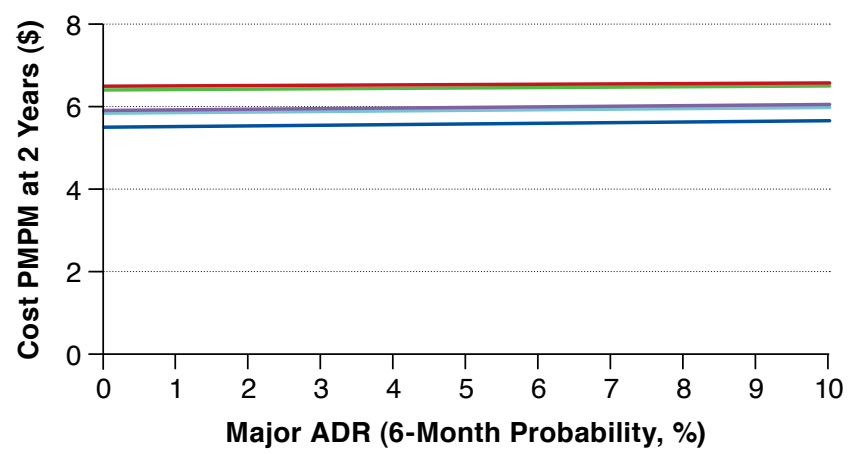

C. TNF-IR Combination Therapy

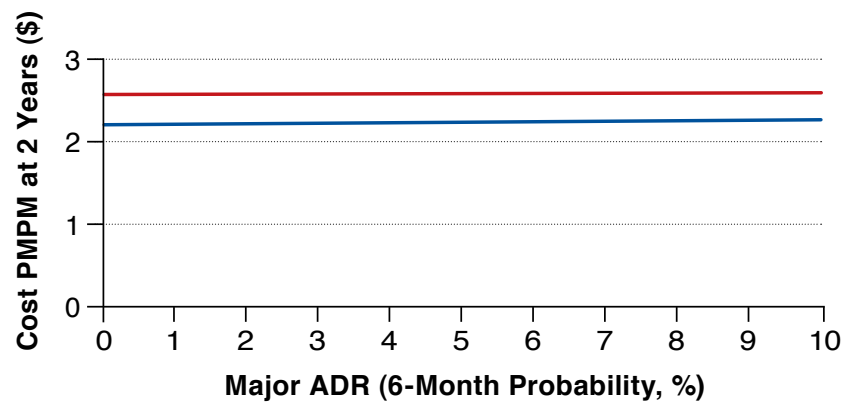

$\begin{array}{ll}\text { - Tofacitinib } & \text { - Adalimumab } \\ \text { Certolizumab } & \text { Tocilizumab }\end{array}$

Note: The impact of varying the major ADR probability for each comparator on the model results is shown here.

$A D R=$ adverse drug reaction; $M T X-I R=$ methotrexate inadequate responder; $P M P M=$ per member per month; TNF-IR=tumor necrosis factor inhibitor inadequate responder.
Finally, the models do not include rebates based on market share of the market-leading products nor does the analysis address any share-shift scenarios or actual forecasting growth trends of each agent in the RA category. The introduction of any new innovative therapy at launch will not have the market share necessary to offset managed care rebates of market leaders; yet, formulary decision makers need to assess cost of care per patient beyond quality-adjusted life-years. In addition, the construction of this model was the result of requests by formulary decision makers for a transparent Excel-based model that could be left with them, so they could conduct their own internal scenario planning. The model is provided to customers only after they receive specific training on its design, editable input fields, assumptions, and output fields. This allows for routine updates to the model based on price increases in the market. Some formulary decision makers lack the time or resources to build or constantly update models based on existing evidence and market dynamics. Providing a transparent, Excel-based model that can be used in concert with decision makers' existing resources has been found to be a useful input for their formulary decisions.

\section{Conclusions}

The strategies of tofacitinib as a second-line therapy following the failure of methotrexate and as a third-line therapy following the failure of a TNF inhibitor therapy appear to be a cost-saving treatment strategy based upon the assumptions used within the model.

Tofacitinib $5 \mathrm{mg}$ twice a day following MTX failure is predicted to be a cost-saving treatment option when used either as monotherapy or combination therapy compared with regimens using other bDMARDs. Tofacitinib in TNF-IR patients was also predicted to be cost saving compared with adalimumab. Tofacitinib was associated with the lowest cost per ACR20 response in both patient subpopulations.

\section{Authors}

LINDSAY CLAXTON, MMath; MICHELLE JENKS, BA, MSc; and MATTHEW TAYLOR, MSc, York Health Economics Consortium, University of York, United Kingdom. GENE WALLENSTEIN, PhD, and ROBERT A. GERBER, PharmD, Pfizer, Groton, Connecticut. ALAN M. MENDELSOHN, MD; JEFFREY A. BOURRET, PharmD; AMITABH SINGH, PhD; and DERMOT MOYNAGH, MSc, Pfizer, Collegeville, Pennsylvania.

AUTHOR CORRESPONDENCE: Lindsay Claxton, MMath, York Health Economics Consortium, Enterprise House, University of York, Heslington, York, YO10 5NQ, United Kingdom.

E-mail: lindsay.claxton@york.ac.uk. 


\section{An Economic Evaluation of Tofacitinib Treatment in Rheumatoid Arthritis: Modeling the Cost of Treatment Strategies in the United States}

\section{DISCLOSURES}

This study was funded by Pfizer, which determined the research topic and paid York Health Economics Consortium to develop the analysis and conduct the research. York Health Economics Consortium has received consultancy fees from Pfizer. Gerber, Wallenstein, Mendelsohn, Bourret, Singh, and Moynagh are employees and shareholders of Pfizer. Editorial support was funded by Pfizer and was provided by Claxton, Jenks, and Taylor, who are employees of York Health Economics Consortium.

Study concept and design were contributed primarily by Taylor, Jenks, Gerber, and Singh, along with the other authors. Gerber, Moynagh, and Singh collected the data, assisted by Bouret and Mendelsohn; data interpretation was performed by Claxton, Gerber, Bouret, and Mendelsohn. The manuscript was written primarily by Claxton, with assistance from the other authors, and revised by Claxton, Gerber, Bouret, and Mendelsohn, with assistance from the other authors.

\section{REFERENCES}

1. Helmick CG, Felson DT, Lawrence RC, et al. Estimates of the prevalence of arthritis and other rheumatic conditions in the United States. Part I. Arthritis Rheum. 2008;58(1):15-25.

2. Myasoedova E, Crowson CS, Kremers HM, Therneau TM, Gabriel SE. Is the incidence of rheumatoid arthritis rising? Results from Olmsted County, Minnesota, 1955-2007. Arthritis Rheum. 2010;62(6):1576-82. Available at: http:// www.ncbi.nlm.nih.gov/pmc/articles/PMC2929692/. Accessed July 22, 2016.

3. Aletaha D, Neogi T, Silman AJ, et al. 2010 Rheumatoid arthritis classification criteria: an American College of Rheumatology/European League Against Rheumatism collaborative initiative. Arthritis Rheum Dis. 2010;69(9):1580-88. Available at: http://ard.bmj.com/content/69/9/1580. long. Accessed July 22, 2016.

4. Prete M, Racanelli V, Digiglio L, Vacca A, Dammacco F, Perosa F. Extraarticular manifestations of rheumatoid arthritis: an update. Autoimmun Rev. 2011;11(2):123-31. Available at: http://www.sciencedirect.com/science/ article/pii/S1568997211001923. Accessed July 22, 2016.

5. Healthcare Cost and Utilization Project (HCUP). National and regional 2012 estimates on hospital use for all patients from the HCUP Nationwide Inpatient Sample (NIS). National statistics-principal diagnosis only. ICD-9-CM 714.0. Agency for Healthcare Research and Quality. Available at: https://www.hcup-us.ahrq.gov/nisoverview.jsp. Accessed July 22, 2016.

6. Cisternas MG, Murphy LB, Yelin EH, et al. Trends in medical care expenditure of US adults with arthritis and other rheumatic conditions 1997 to 2005. J Rheumatol. 2009;36(11):2531-38.

7. Singh JA, Saag KG, Bridges SL Jr, et al. 2015 American College of Rheumatology Guidelines for the treatment of rheumatoid arthritis. Arthritis Rheumatol. 2016;68(1):1-26. Available at: http://www.rheumatology.org/ Portals/0/Files/ACR\%202015\%20RA\%20Guideline.pdf. Accessed July 22, 2016.

8. Smolen JS, Landewé R, Breedvelt FC, et al. EULAR recommendations for the management of rheumatoid arthritis with synthetic and biological diseasemodifying antirheumatic drugs. Ann Rheum Dis. 2010;69(6):964-75. Available at: http://ard.bmj.com/content/69/6/964.long. Accessed July 22, 2016.

9. Matsumoto AK, Bathon J, Bingham CO III. Rheumatoid arthritis treatment. The Johns Hopkins Arthritis Center. Updated March 21, 2016. Available at: http://www.hopkinsarthritis.org/arthritis-info/rheumatoidarthritis/ra-treatment/. Accessed July 22, 2016.

10. Hyrich KL, Lunt M, Watson KD, et al. Outcomes after switching from one anti-tumor necrosis factor alpha agent to a second anti-tumor necrosis factor alpha agent in patients with rheumatoid arthritis: results from a large UK national cohort study. Arthritis Rheum. 2007;56(1):13-20.

11. Kamal KM, Madhavan SS, Hornsby JA, Miller LA, Kavookjian J, Scott V. Use of tumor necrosis factor inhibitors in rheumatoid arthritis: a national survey of practicing United States rheumatologists. Joint Bone Spine. 2006;73(6):718-24
12. Rubbert-Roth A, Finckh A. Treatment options in patients with rheumatoid arthritis failing initial TNF inhibitor therapy: a critical review. Arthritis Res Ther. 2009;11(Suppl 1):S1. Available at: http://www.ncbi.nlm.nih.gov/ pmc/articles/PMC2669237/pdf/ar2666.pdf. Accessed July 22, 2016.

13. XELJANZ (tofacitinib) tablets, for oral use. Pfizer. Revised June 2015 Available at: http://www.accessdata.fda.gov/drugsatfda_docs/label/2015/ 203214s010lbl.pdf. Accessed July 22, 2016.

14. Fleischmann R, Kremer J, Cush J, et al. Placebo-controlled trial of tofacitinib monotherapy in rheumatoid arthritis. N Engl J Med. 2012;367(6):495-507. Available at: http://www.nejm.org/doi/full/10.1056/NEJMoal109071. Accessed July 22, 2016

15. van Vollenhoven RF, Fleischmann R, Cohen S, et al. Tofacitinib or adalimumab versus placebo in rheumatoid arthritis. N Engl J Med. 2012;367(6):508-19. Available at: http://www.nejm.org/doi/full/10.1056/ NEJMoal112072. Accessed July 22, 2016.

16. Burmester GR, Blanco R, Charles-Schoeman C, et al. Tofacitinib $($ CP-690,550) in combination with methotrexate in patients with active rheumatoid arthritis with an inadequate response to tumour necrosis factor inhibitors: a randomised phase 3 trial. Lancet. 2013;381(9865):451-60.

17. Kremer J, Li ZG, Hall S, et al. Tofacitinib in combination with nonbiologic disease-modifying antirheumatic drugs in patients with active rheumatoid arthritis: a randomized trial. Ann Intern Med. 2013;159(4):253-61.

18. van der Heijde D, Tanaka Y, Fleischmann R, et al. Tofacitinib $(C P-690,550)$ in patients with rheumatoid arthritis receiving methotrexate: twelve-month data from a twenty-four-month phase III randomized radiographic study. Arthritis Rheum. 2013;65(3):559-70.

19. U.S. Food and Drug Administration. Guidance for industry. Clinical development programs for drugs, devices, and biological products for the treatment of rheumatoid arthritis (RA). February 1999. Available at: http:// www.fda.gov/downloads/Drugs/../Guidances/ucm071579.pdf. Accessed July 22, 2016.

20. Vieira MC, Wallenstein GV, Bradley JD, et al. Tofacitinib versus biologic treatments with and without methotrexate in patients with active rheumatoid arthritis who have had an inadequate response to traditional disease modifying anti-rheumatic drugs—a network meta-analysis. Ann Rheum Dis. 2012;71(Suppl 3):375

21. National Institute for Health and Care Excellence. Adalimumab, etanercept, infliximab, rituximab and abatacept for the treatment of rheumatoid arthritis after the failure of a TNF inhibitor. NICE technology appraisal guidance [TA195]. August 25, 2010. Available at: https://www.nice.org.uk/ guidance/ta195. Accessed July 22, 2016.

22. Rituxan (rituximab) injection for intravenous use. Genentech. Revised February 2010. Available at: http://www.accessdata.fda.gov/drugsatfda_docs/ label/2010/103705s531llbl.pdf. Accessed July 22, 2016.

23. Van de Putte LBA, Atkins C, Malaise M, et al. Efficacy and safety of adalimumab as monotherapy in patients with rheumatoid arthritis for whom previous disease modifying antirheumatic drug treatment has failed. Ann Rheum Dis. 2004;63(5):508-16. Available at: http://www.ncbi.nlm.nih.gov/ pmc/articles/PMC1755008/. Accessed July 22, 2016.

24. Keystone EC, Kavanaugh AF, Sharp JT, et al. Radiographic, clinical, and functional outcomes of treatment with adalimumab (a human anti-tumor necrosis factor monoclonal antibody) in patients with active rheumatoid arthritis receiving concomitant methotrexate therapy. Arthritis Rheum. 2004;50(5):1400-11.

25. Moreland LW, Schiff MH, Baumgartner SW, et al. Etanercept therapy in rheumatoid arthritis. A randomized, controlled trial. Ann Intern Med. 1999;130(6):478-86.

26. Weinblatt ME, Kremer JM, Bankhurst AD, et al. A trial of etanercept, a recombinant tumor necrosis factor receptor:Fc fusion protein, in patients with rheumatoid arthritis receiving methotrexate. N Engl J Med. 1999;340(4):253-59. Available at: http://www.nejm.org/doi/full/10.1056/ NEJM199901283400401. Accessed July 22, 2016. 


\section{An Economic Evaluation of Tofacitinib Treatment in Rheumatoid Arthritis: Modeling the Cost of Treatment Strategies in the United States}

27. Fleischmann R, Vencovsky J, van Vollenhoven RF, et al. Efficacy and safety of certolizumab pegol monotherapy every 4 weeks in patients with rheumatoid arthritis failing previous disease-modifying antirheumatic therapy: the FAST4WARD study. Ann Rheum Dis. 2009;68(6):805-11. Available at: http://ard.bmj.com/content/68/6/805.long. Accessed July 22, 2016.

28. Keystone E, van der Heijde D, Mason D Jr, et al. Certolizumab pegol plus methotrexate is significantly more effective than placebo plus methotrexate in active rheumatoid arthritis: findings of a fifty-two-week, phase III, multicenter, randomized, double-blind, placebo-controlled, parallel-group study. Arthritis Rheum. 2008;58(11):3319-29.

29. Dougados M, Kissel K, Sheeran T, et al. Adding tocilizumab or switching to tocilizumab monotherapy in methotrexate inadequate responders: 24-week symptomatic and structural results of a 2-year randomized controlled strategy trial in rheumatoid arthritis (ACT-RAY). Ann Rheum Dis. 2013;72(1):43-50. Available at: http://ard.bmj.com/content/72/1/43.long. Accessed July 22, 2016.

30. Kremer JM, Blanco R, Brzosko M, et al. Tocilizumab inhibits structural joint damage in rheumatoid arthritis patients with inadequate responses to methotrexate: results from the double-blind treatment phase of a randomized placebo-controlled trial of tocilizumab safety and prevention of structural joint damage at one year. Arthritis Rheum. 2011;63(3):609-21.

31. Cohen SB, Emery P, Greenwald MW, et al. Rituximab for rheumatoid arthritis refractory to anti-tumor necrosis factor therapy: results of a multicenter, randomized, double-blind, placebo-controlled, phase III trial evaluating primary efficacy and safety at twenty-four weeks. Arthritis Rheum. 2006;54(9):2793-806.

32. Genovese MC, Becker JC, Schiff M, et al. Abatacept for rheumatoid arthritis refractory to tumor necrosis factor alpha inhibition. N Engl J Med. 2005;353(11):1114-23. Available at: http://www.nejm.org/doi/full/10.1056/ NEJMoa050524. Accessed July 22, 2016.

33. Felson DT, Anderson JJ, Boers M, et al. American College of Rheumatology. Preliminary definition of improvement in rheumatoid arthritis. Arthritis Rheum. 1995;38(6):727-35.

34. Malottki K, Barton P, Tsourapas A, et al. Adalimumab, etanercept, infliximab, rituximab and abatacept for the treatment of rheumatoid arthritis after the failure of a TNF inhibitor: a systematic review and economic evaluation. West Midlands Health Technology Assessment Collaboration. November 24 2009. Available at: https://www.nice.org.uk/guidance/tal95/documents/ rheumatoid-arthritis-drugs-for-treatment-after-failure-of-a-tnf-inhibitor-acdadalimumab-etanercept-infliximab-rituximab-and-abatacept-for-the-treatment-of-rheumatoid-arthritis-after-the-failure-of-a2. Accessed July 22, 2016.
35. Greenberg JD, Reed G, Decktor D, et al. A comparative effectiveness study of adalimumab, etanercept and infliximab in biologically naive and switched rheumatoid arthritis patients: results from the US CORRONA registry. Ann Rheum Dis. 2012;71(7):1134-42.

36. Strand V, Ahadieh S, French J, et al. Systematic review and meta-analysis of serious infections with tofacitinib and biologic disease-modifying antirheumatic drug treatment in rheumatoid arthritis clinical trials. Arthritis Res Ther. 2015;17:362. Available at: http://www.ncbi.nlm.nih.gov/pmc/articles/ PMC4704538/. Accessed July 22, 2016.

37. HUMIRA (adalimumab) injection, for subcutaneous use. Abbott Laboratories. Revised September 2012. Available at: http://www.accessdata.fda. gov/drugsatfda_docs/label/2012/125057s232lbl.pdf. Accessed July 22, 2016.

38. Enbrel (etanercept) solution for subcutaneous use. Amgen and Pfizer. Revised December 2012. Available at: http://www.accessdata.fda.gov/drugsatfda_docs/label/2012/103795s5503lbl.pdf. Accessed July 22, 2016.

39. CIMZIA (certolizumab pegol) for injection, for subcutaneous use. UCG, Inc. Revised October 2015. Available at: http://www.accessdata.fda gov/drugsatfda_docs/label/2015/125160s264lbl.pdf. Accessed July 22, 2016.

40. ACTEMRA (tocilizumab) injection, for intravenous infusion. Genentech. Available at: http://www.accessdata.fda.gov/drugsatfda_docs/ label/2010/125276lbl.pdf. Accessed July 22, 2016.

41. ORENCIA (abatacept) lyophilized powder for intravenous infusion. Bristol-Myers Squibb Company. Revised August 2009. Available at: http:// www.accessdata.fda.gov/drugsatfda_docs/label/2009/125118s0086lbl.pdf. Accessed July 22, 2016.

42. Truven Health Analytics. RED BOOK Online. September 2015.

43. InGauge Health Care Solutions. Physicians' Fee \& Coding Guide 2015. Atlanta, GA: InGauge Health Solutions; March 2015.

44. Saag KG, Teng GG, Patkar NM, et al. American College of Rheumatology 2008 recommendations for the use of nonbiologic and biologic diseasemodifying antirheumatic drugs in rheumatoid arthritis. Arthritis Rheum. 2008;59(6):762-84.

45. Lee MY, Park SK, Park SY, et al. Cost-effectiveness of tofacitinib in the treatment of moderate to severe rheumatoid arthritis in South Korea. Clin Ther. 2015;37(8):1662-76. 